\title{
Technology of the Self and Classroom Management-A Systematic Approach for Teacher Students
}

\author{
Gisela Steins, Anna Haep, Katharina Wittrock \\ Institut für Psychologie, Fakultät für Bildungswissenschaften, Universität Duisburg-Essen, Duisburg, Germany \\ Email: gisela.steins@uni-due.de
}

Received 8 September 2015; accepted 20 November 2015; published 23 November 2015

Copyright (C) 2015 by authors and Scientific Research Publishing Inc.

This work is licensed under the Creative Commons Attribution International License (CC BY). http://creativecommons.org/licenses/by/4.0/

(c) (i) Open Access

\section{Abstract}

In order to reduce the relatively high burden of teaching profession and to improve teachers' skills in their interactions with students, a systematic introduction to Technologies of the Self and a continuous training of their use should be established in Teacher Education. We explored whether students in Teacher Education classify rational-emotive behavior therapy (REBT) as a useful Technology of the Self. We taught the basics of REBT in a university setting in addition to the traditional contents of Classroom Management research. Using a repeated-measures design, we explored the results of implementing Classroom Management research including a continuous and systematic teaching and training of a Technology of the Self that was based on REBT $(N=110$ teacher students). We assessed varying degrees of realism in teaching (low, medium, high, control). The students evaluated the courses before (T1) and after taking them (T2) regarding their usefulness for teaching profession. The trainees also evaluated the usefulness of the course content 6 months after the course was finished (T3). The results show that applying a systematic Technology of the Self such as REBT and its affiliated rational emotive education (REE) is quite necessary and should be given high priority in teaching Classroom Management (CM).

\section{Keywords}

Technology of the Self, Classroom Management, Rational-Emotive Behavior Therapy, Teacher Stress

\section{Introduction}

The aim of this paper is to draw attention to the fact that a systematic introduction to Technologies of the Self 
and a continuous training of their use should be applied in Teacher Education in order to reduce the relatively high burden of teaching profession and to improve teachers' skills in their interactions with students. Previous attempts to consider the importance of Technology of the Self in Teacher Education lack a theoretical and evidence-based system of classification. Technologies of the Self include systematic techniques of self reflection and regulation of emotions and behavior. Technologies of the Self allow individuals to perceive reality adequately, to act appropriately, and to recognize and influence their own negative emotions (Ellis, 1994; Foucault, 1984). Technologies of the Self, as used in our research, can be seen as strategies and techniques that allow a person to establish a dialogue with him or herself, in German: Zwiegespräch, which includes a critical discussion of one's own relevant cognitive representations (Löfström et al., 2013).

This paper presents the advantages of using Technology of the Self as a relevant part of Classroom Management (CM) in teaching profession through the theory and practice of rational-emotive behavior therapy (REBT). In the first step, we present some of the key arguments for the use of Technologies of the Self in teaching profession. In the empirical part of the paper, we explore how a continuous and systematic program for CM, including teaching and training of a Technology of the Self that is based on REBT can be implemented in a university setting.

\section{The Relevance of Technology of the Self in Teaching Profession}

The core argument about the use of Technology of the Self in teaching profession can be found in research on stress and strain. In particular, burnout, depression, and psychosomatic diseases are the main causes of premature retirement in teaching profession (Bauer, Unterbrink, Hack, Pfeifer, Buhl-Grießhaber et al., 2007; Black, 2003; Schwarzer, Schmitz, \& Tang, 2000; Friedman, 1995, 2006; Ullrich, Lambert, \& McCarthy, 2012; Unterbrink et al., 2012; Weber, Weltle, \& Lederer, 2004). In this research context, the urgency for teachers to become familiar with techniques that allow them to identify and reduce stressors has repeatedly been emphasized (Fleming, Mack Rain, \& LeBuffe, 2013; Friedman, 2006; Doll, 2013; Maag, 2001, 2008; Nucci, 2002; Wilton \& Steins, 2012). An analysis by Weber et al. (2004) on the retirement behavior of teachers in Germany showed that the proportion of disease-related early retirements in teachers ranges from $50 \%$ to $60 \%$. Using a sample of 949 German teachers, Bauer et al. (2007) found that “... nearly 30\% of teachers suffer from significant mental health problems" (p. 442). The research findings regarding stress in teaching profession clearly show that interaction difficulties with students, parents, and colleagues are the most relevant stressors in this profession (Bauer et al., 2007; Black, 2003; Friedman, 1995, 2006; Hastings \& Bham, 2003; Unterbrink et al., 2012)”. Teachers ... deal with a remarkable extent of adverse events caused by pupils and/or parents (Bauer et al., 2007: p. 448). Maag (2008) summarized the most stressful behaviors of students as disrespect, inattentiveness, low motivation, poor achievement, apathy, and social incompetence.

As a result, several programs have been created to increase teachers' social and emotional skills by providing preventative knowledge (e.g., knowledge about the development of stress) and preventative coping strategies. The Teacher Training Program by Piwowar, Thiel and Ophardt (2013) provides a systematic connection between practical and theoretical expertise and learning, role-play, and simulations in the context of Classroom Management for teachers. So far, the systematic teaching of these skills has lagged behind the teaching of other skills in Teacher Education (O'Neill \& Stephenson, 2012). According to the Balint model, supervision groups are proposed as a means for skill enhancement (Bauer et al., 2007). These models, techniques, and knowledge have positive effects (Piwowar et al., 2013) and clearly convey the preventative effects of different techniques and skills.

Another supporting argument of a systematic implementation of Technologies of the Self in teaching profession focuses on methods of interacting with adolescents. A caring and friendly but simultaneously demanding method of interacting with adolescents is considered to represent a mature parenting style (Knaus, 1974; Doll, 2013). This method of interacting supports the positive development of adolescents, as cognitive and emotional development merges. Therefore, the method of interacting in the instructional setting has effects on adolescents' emotional and social development. Students with emotional and social difficulties, in particular, benefit from this method of interacting (Den Brok \& Levy, 2005; Hamre \& Pianta, 2001, 2005; Liew, Chen, \& Hughes, 2010; Reyes, Elias, Parker, \& Rosenblatt, 2013; Shechtman \& Leichtentritt, 2004; Sleeter, 2008; Steins \& Haep, 2014; Weinstein, Tomlinson-Clarke, \& Curran, 2004). To practice the so-called "mature style of education”, an aboveaverage ability to reflect on one's own emotions and beliefs is required. It can be assumed that teachers with a 
very high level of stress will not succeed in behaving in accordance with a mature educational style (Friedman, 2006; Maag, 2008). The more burdened the teachers feel, the more negatively they evaluate the behavior of students, and the more dysfunctional their actions are (Kokkinos, 2005). Fleming et al. (2013) pointed to direct negative effects of such behavior on the development of adolescents. The knowledge and use of Technologies of the Self are therefore highly relevant for dealing appropriately with students. This positively affects both the health maintenance of teachers and the adolescents' development support, which is at risk without rational and relaxed models (Doll, 2013; Reyes et al., 2013; van Tartwijk, Den Brok, Veldman, \& Wubbels, 2009).

Teachers often find themselves working under difficult circumstances, combined with a professional socialization that is not sufficient for preparing them for such conditions. There are many examples in the literature where this co-occurrence of unfavorable external conditions and insufficiently developed individual professional skills is discussed (e.g., Den Brok \& Levy, 2005; Jones, 2006; Rushton, 2000). Technologies of the Self, such as REBT, explore the processes that allow individuals to perceive reality adequately, to act appropriately, and to recognize and manage their own negative emotions.

In summary, on the basis of the current state of research, it can be argued that first, Technologies of the Self in Teacher Education are important for preventing early exit from the profession and the occurrence of mental disorders. Second, they also support a useful context that can benefit both teachers and students.

\section{The Specifics of Teaching Profession}

The mastery of a systematic Technology of the Self can be of great benefit in many contexts. In the context of teaching profession, however, it is remarkable that the transfer of Technologies of the Self has yet to play a significant role. In teaching profession, the quality of the professionals' interaction style is as important as for medical doctors, judges, the police, and so forth. However, the key difference is the capacity to manage the complexity of teaching profession. An activity in small and manageable social settings does not require such high capacity to manage complexity as in the teaching profession (Dollase, 2012; Loewenberg Ball \& Forzani, 2009, 2010; Steins, Bitan, \& Haep, 2014).

\subsection{A View on Classroom Management}

CM is very often equated with order and discipline, especially by students in Teacher Education (Stoughton, 2007). In fact, the field of CM is a lot wider. On one hand, CM includes individual support, which is specifically addressed in Evertson and Weinstein's (2006) definition with respect to the cognitive, emotional, and moral development of adolescents. On the other hand, it also includes skills in dealing with a large study group and the potential problems related to such a situation (Dollase, 2012; Kounin, 1970). Dollase (2012) pointed out that challenges in the classroom are increased by the fact that teaching takes place in a group and not in a 1:1 interaction. Because of this, complexity is increased and is complicated by variables as the public nature of teaching and the relationship structure that are inevitably formed among students. A teacher may have available acceptance, empathy, praise, humor, and justice and be able to establish friendly interactions and provide support for the self-regulation of individual students (Dollase, 2012). In addition, knowledge about social processes is helpful. In our research we tried to include the basic knowledge that might be important for CM in our seminars and described the contents in more detail (Steins, Wittrock, \& Haep, 2015).

A question that is often discussed is how the content of CM might be transferred in such a way that it would be available in the professional setting. Answers to this question are important. Knowledge can be very futile and is not necessarily transferred in competencies. In addition, there is a certain pressure to use the short time in teacher education which is dedicated CM very efficiently.

However there is no agreement about the specific practices that new teachers should be able to carry out competently before they take responsibility of a classroom, and no assessment that measures their capability with particular practices (Forzani, 2014).

In addition, there is no agreement on how to teach CM. Opinions about the usefulness of training versus experience are different. Table 1 lists the conflicting arguments of researchers about this question. Our design includes an exploration of this question. This disagreement concerns teacher education in general: Jones (1996) pointed out that "little work has been done to determine the most effective methods of educating teachers." (p. 515). 
Table 1. How to teach CM?

\begin{tabular}{|c|c|}
\hline Argument & Reference \\
\hline \multicolumn{2}{|c|}{ Behavior Training } \\
\hline \multicolumn{2}{|c|}{ Pro } \\
\hline $\begin{array}{l}\text { Forcing themselves to behave differently } \\
\text { from how they are feeling. }\end{array}$ & Maag, 2008 \\
\hline $\begin{array}{l}\text { Special Training for behavior is necessary; communicating } \\
\text { knowledge is not sufficient; work of teaching. }\end{array}$ & Forzani, 2014; Loewenberg Ball \& Forzani, 2009, 2010 \\
\hline \multicolumn{2}{|c|}{ Contra } \\
\hline $\begin{array}{l}\text { While field experiences are essential, they often encourage } \\
\text { replication rather than critical questioning. }\end{array}$ & Sleeter, 2008 \\
\hline \multicolumn{2}{|c|}{ Experiences and Reflection } \\
\hline \multicolumn{2}{|c|}{ Pro } \\
\hline Reflections on experiences may lead to changes in beliefs. & Walkington, 2005 \\
\hline $\begin{array}{l}\text { Through exploring their beliefs about teaching, students can be } \\
\text { assisted in reflecting critically on the decisions they make and can } \\
\text { learn to monitor their own professional development. }\end{array}$ & Leavy et al. 2007 \\
\hline $\begin{array}{l}\text { Little or no professional pedagogical knowledge of value can be } \\
\text { learned other than through experience. }\end{array}$ & Zeichner, 2003 \\
\hline \multicolumn{2}{|c|}{ Contra } \\
\hline $\begin{array}{l}\text { Reflection with case studies. Case studies find a single } \\
\text { such experience as likely to reinforce } \\
\text { deficit perspectives about students. }\end{array}$ & Sleeter, 2008 \\
\hline $\begin{array}{l}\text { "Teachers have typically bridged the knowing-doing gap by } \\
\text { having experience and improvising.” Some teachers } \\
\text { left to learn through experience to manage their } \\
\text { classrooms using harshly punitive methods. }\end{array}$ & Loewenberg Ball \& Forzani, 2009: p. 42 \\
\hline \multicolumn{2}{|c|}{ Combinations } \\
\hline $\begin{array}{l}\text { Didactic instruction s about basic concepts, skills, } \\
\text { experiences, case studies and simulations. }\end{array}$ & Jones, 2006 \\
\hline $\begin{array}{l}\text { Approximations of practice as a complex interplay } \\
\text { of learning and competency, identity work. }\end{array}$ & Trent, 2013 \\
\hline
\end{tabular}

Although various valuable ideas from CM research are available, CM research has not been systematically integrated with Teacher Education yet (Evertson \& Weinstein, 2006; Jones, 2006; O’Neill \& Stephenson, 2012; Piwowar et al., 2013; Stough, 2006). Especially in the light of reforms in the school system, appropriate training for real-life situations has become even more unlikely (Zeichner, 2005).

\subsection{Classroom Management and Technology of the Self}

In CM research, the importance of Technologies of the Self is clearly seen as a prerequisite for development-promoting and health-preserving behavior and for addressing the many skills required for dealing with a larger group of young people in a school context. The ability of teacher students to reflect on themselves and to develop appropriate ideas about the reality of school and their required behavior is very important. However, teacher students effectively have no systematic self-knowledge even after their training and are not equipped with systematic techniques for self-reflection and self-regulation. Numerous findings have shown that teacher students' views on their profession do not significantly change from immediately before they begin their education to immediately after they complete it (Blömeke, Buchholtz, Suhl, \& Kaiser, 2014; Löfström \& Poom Valickis, 2013). Opinions about how to behave as a teacher and how to interact with students are formed during their personal education in school as students by observing their own teachers. These opinions are apparently not questioned during the entire duration of their training. New information is filtered and assimilated into a belief 
system that is developed early (Balli, 2011; Blömeke et al., 2014; Hattie, 2009; Jones, 2006; Löfström et al., 2013; Stoughton, 2007).

We assume that a systematic application of the Technology of the Self, in which teachers in education would be encouraged to question their belief systems, does not take place. An adaptation of a person's own belief system to empirical evidence does not take place due to the lack of the Technology of the Self (Löfström et al., 2013). Here, we see a significant gap in the core of Teacher Education but also in further education of teachers.

In summary, despite the fact that the importance of evidence-based Technologies of the Self has long been recognized, the what and how of a systematic implementation of them are still underrepresented and neglected in $\mathrm{CM}$ research and Teacher Education.

\subsection{REBT as a Technology of the Self}

A good Technology of the Self is committed to reality. Many findings in educational research have shown that it is important that teachers behave realistically and that their behavior corresponds with reality. Educational research shows that teachers who are able to view learning from the eyes of the students are better able to contribute to students' learning progress (Hattie, 2009). This form of teaching requires teachers to see students individually for who they are and to be aware of the influences that may distort their own social perceptions.

With the help of Albert Ellis' ABC-model, teacher students learn the connection of (activating) events (A), thoughts or beliefs (B) and consequences (C) (Ellis, 1994). Ellis states that this connection most notably depends on how a person estimates an event and also on how this person will feel and act according to the estimation (for more details see Bitan, Haep \& Steins, 2013). Thus, a very important insight for teacher students is to realize, that not only the activating events are important, but also the beliefs and thoughts of a person are central to emotional reactions. According to REBT, beliefs can be divided into two categories: irrational, not helpful thoughts and rational, helpful thoughts. Therefore, Beliefs about certain events also have a big influence on the code of interaction with different persons as well. A person's individual beliefs (B) about activating events (A) have a large influence on the emotional reactions and the behavior $(\mathrm{C})$. A trigger for irrational thoughts and beliefs can be absolutistic demands, divided into three categories by Ellis: Demands concerning the world ("Everything should work out the way I want it to."), demands regarding others ("Students should act exactly as I want them to.”) and self-demands ("I should perform better at school. Without being liked by my students, I'm a useless person.”).

Knowledge about a Technology of the Self such as REBT, might help to internalize why some beliefs and thoughts, emotions and behaviors are not helpful. By understanding and accepting the B-C-connection, teacher students are probably enabled to take over the responsibility for their thoughts, beliefs and emotions and do not have to blame others any longer.

To a large degree, REBT as a Technology of the Self represents an exercise in reality orientation. It includes an important tradition of investigating reality-distorting cognitions and any associated emotions and behaviors, and knowledge about REBT is helpful for self-knowledge, thinking, feeling, and acting (Ellis, 1994; David, Lynn, \& Ellis, 2010). Through exploration strategies, a person is able to recognize his or her own unhelpful patterns of thinking and can then actively change such patterns by implementing several strategies at different levels. Several studies have pointed out that the dysfunctional beliefs in teaching profession play an important role in problem escalation, stress, and premature drop-out (Rauin \& Meyer, 2007; Unterbrink et al., 2012). Friedman, for example, explicitly stressed the unrealistic expectations of teachers who suffer from burnout (2006). A teacher for example who wants to be liked by the students might experience more emotional conflicts than a teacher who just wants to be respected by the students, especially if not being liked is equated with being a worthless person. Further research has shown that in many cases, teachers enter the professional field with a certain degree of naivety; the ensuing reality can then be shocking (Balli, 2011; Löfström et al., 2013).

REBT has all the advantages of a systematic and falsifiable theory (Bitan, Haep, \& Steins, 2013). Some authors have already described research on the use of REBT in teaching profession. Warren (2013) argued that REBT could increase the self-efficacy of teachers. Research by Maag demonstrated that REBT is perceived as useful by teachers (2008). According to Black’s (2003) results, Technologies of the Self are important for more than just working on school-related problems. Black showed that teachers tend to bring their own personal problems to school, such as problems in their personal relationships and finances and these problems can then increase their perceived stress at work. 
On a theoretical level, REBT could be applied to address an outstanding issue, namely, the way individuals deal with prevailing circumstances have an impact on themselves and their environment. In the school context, this discussion has not been sufficiently addressed on a systematic basis. This can be briefly illustrated by the example of burnout research. On one hand, Maslach and Leiter (1997) emphasized the difficult conditions encountered in various professional contexts, especially considering the background of increasing international competitiveness. Schaarschmidt (2009) represented this position in Germany in teacher research and supplied evidence from teachers' self-reports. On the other hand, there is equally convincing research in which the individual dealing with demands plays a major role. Friedman (2006), for example, emphasized the major role of unrealistic expectations in people suffering from burnout. Rauin et al. (2007) provided compelling longitudinal data from German teacher students since they began their studies until their early years as professionals. The authors came to the conclusion that people suffering from burnout never thrived or were already overwhelmed by the challenges of their educational setting.

These positions may be part of a complex interaction within the central analysis model of REBT (Activating Event, Beliefs, and Consequences), and this is why the situation along with its various interpretations are the subjects of a detailed analysis. Certain situations trigger certain emotions, but the quality and intensity of emotions are primarily created by a person's own interpretations and conclusions (Bitan et al., 2013; Ellis, 1994).

\section{Our Research}

We examined different forms of CM training with teacher students in which REBT was granted a fundamental role as a Technology of the Self. We tried to answer various questions with these different trainings: How do teacher students rate the learning of the Technology of the Self? How does it compare with the content of classic CM? In our previous research we tried to gain knowledge about the possibilities of content arrangements (Steins, Wittrock, \& Haep, 2015). Here, we aim to include the teacher students' perspective on the contents' usefulness on a deeper level.

How can CM techniques, including a Technology of the Self such as REBT, best be taught?

\section{Method}

\subsection{Setting and Sample}

The data used in the present study were collected in a university setting. One hundred and ten teacher students were interviewed in different courses with the help of a questionnaire at the beginning and end of the semester; 29 (26.36\%) students were male, and 81 (73.64\%) were female. The average age of the sample was 24.41 ( $S D=$ $3.52)$.

\subsection{Design}

We employed a pre-post design including three points of measurement (beginning of the course: T1; after the course: T2; 6 months after the course: T3). Figure 1 gives an overview about the design. Twelve 90-minute meetings within a time period of 3 to 6 months took place between T1 and T2. The research design involved four groups characterized by different degrees of realism with respect to content transfer. A low degree of realism is defined as teaching CM only on a theoretical level. A medium degree of realism is characterized by mixing theory with role plays. A high degree of realism consists in teaching on a theoretical level, mixing theory with role plays and teaching in real classrooms combined with observation and feedback. The group with low grade of realism (LGR) included 22 students who attended a seminar on CM, which was characterized exclusively by traditional academic teaching theory. The content was presented via computerized presentations and was discussed with the students. The same content was explored more deeply with the students $(N=35)$ in the "moderate grade of realism" (MGR) group by means of simulations and role-playing. Again, there were sequences of theoretical lectures that were illustrated with various exercises. The students in the "high grade of realism" (HGR; $N=22$ ) group received 12 sessions of teaching theory and then directly applied their acquired knowledge in a series of teaching lessons to adolescents attending our partner schools. There, the teacher students taught social learning once a week for 90 min (to seventh and third graders). Every teacher student received feedback in the group setting but also individually (Steins \& Haep, 2015). For this group, the seminar lasted twice as long ( 6 months $=3$ months theory +3 months theory and practice). The control group included 


\begin{tabular}{|c|c|c|c|c|}
\hline & \multicolumn{3}{|c|}{ CM-Training-Group ${ }^{1}$} & \multirow{2}{*}{$\begin{array}{c}\text { Control Group } \\
\text { (N=31; } 3 \\
\text { months) }\end{array}$} \\
\hline & $\begin{array}{l}\text { Low Grade of Realism } \\
\text { ( }=22 ; 3 \text { months) }\end{array}$ & $\begin{array}{l}\text { Moderate Grade of } \\
\text { Realism ( }=35 ; 3 \text { months) }\end{array}$ & $\begin{array}{l}\text { High Grade of Realism } \\
(\mathrm{N}=22 ; 6 \text { months) }\end{array}$ & \\
\hline T1 & \multicolumn{4}{|c|}{$\begin{array}{c}\text { Perception of complexity } \\
\text { Resilience } \\
\text { Cooperation } \\
\text { Prosociality } \\
\text { Education readiness } \\
\text { CM knowledge } \\
\text { Self-efficacy } \\
\text { Attitudes towards profession } \\
\end{array}$} \\
\hline
\end{tabular}

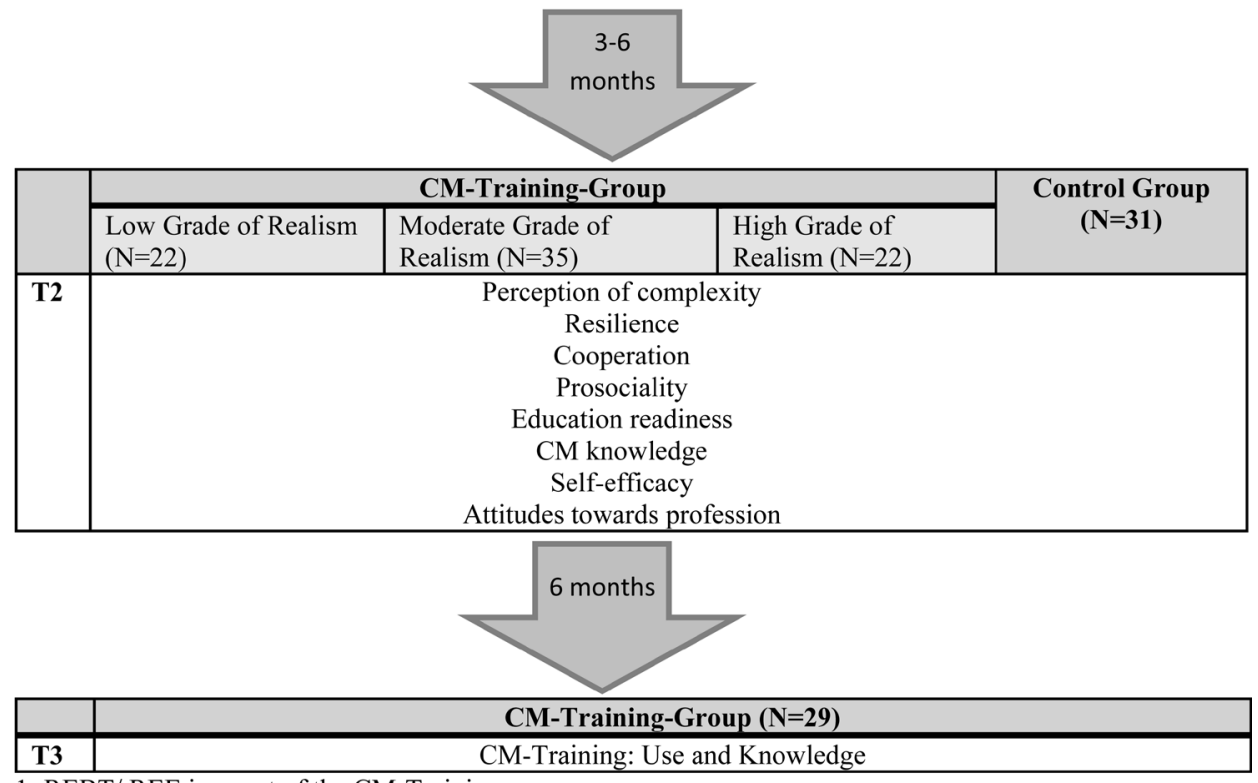

1: REBT/ REE is a part of the CM-Training

Figure 1. Design of the study.

students from a course on social psychology (CG; $N=31$ ). The seminars were conducted by five different lecturers.

Students could volunteer to take a short questionnaire on the relevance of the course topics and their usefulness 6 months after completing the seminars.

\subsection{Knowledge Content}

The theoretical content of CM included the following topics: definitions of CM, research on CM, parenting styles, cultural aspects of educational ideas, REE and REBT, ecological psychology, Positive Behavior Support Systems, and social perception were discussed for approximately equal amounts of time (for a more detailed descriptions of these contents see Steins, Wittrock, \& Haep, 2015). Bullying as a special topic was only relatively briefly mentioned. The students in the control group were familiar with social psychological theories in which the particular school reference was discussed (based on Steins, 2014). REBT and REE were not the topics of discussion in this lecture.

\subsection{Survey}

Survey at T1 and T2: Quantitative data. Using Kanning, Herrmann, and Böttcher (2011) as a foundation, we developed questionnaire statements that have been shown to be relevant to teaching profession. For our research question, we adapted five different scales, namely, the perception of complexity (9 items, e.g., "I am good at registering what is happening"), resilience (8 items, e.g., "I cannot stand disputes"), cooperation (12 items, e.g., "It is often helpful not to be alone when addressing problems”), pro-sociality(9 items, e.g., "Other people’s problems affect me”), and education readiness (14 items, e.g., “An important task of school is education”). The ques- 
tions were rated on a 5-point scale $(1=$ strongly disagree, 5 = strongly agree). Two questions were self-assessments of the respondent's own CM skills (e.g., "How high is your expertise in CM? Give yourself a grade"; 1 = high expertise, $5=$ low expertise). Furthermore, we used a self-efficacy short scale that was based on Schmitz and Schwarzer (2000). Schwarzer, Schmitz, and Tang (2000) posited that self-efficacy plays a role in preventing stress and burnout. The seven items used here (e.g., "Even if my teaching is disturbed, I'm sure that I can preserve the necessary serenity") were rated with respect to how well they applied to the respondent on a 4-point scale $(1=$ not true, 2 = barely true, $3=$ fairly true, $4=$ exactly right $)$. Furthermore, we asked two questions about students' attitudes toward the profession with the same rating scale (e.g., "I am looking forward to my profession and related activities") and a question about satisfaction with their previous training $(1=$ high satisfaction, 5 = low satisfaction).

All these questions were presented to the students at both $\mathrm{T} 1$ and $\mathrm{T} 2$.

Survey at T1 and T2: Qualitative data (HGR). In addition to the questions listed above, the students in the HGR group had to provide a reflective report on the relevant content of the seminar after completing the theory section of the seminar. They provided another set of reports after completing the practice phase.

Survey after 6 months (T3): Quantitative and qualitative data. All teacher students in the CM seminars could volunteer to participate in a survey that was administered at least 6 months after the seminar. If consent was given, a short questionnaire was sent electronically. Twenty-nine students handed in the questionnaire; 18 students were female and nine were male, whereas two people did not specify their gender.

In order to establish the teacher students' motivation for working on the questionnaire, they were asked a total number of only five questions. In the first step, we asked if the teacher students had been involved with topics of CM since completing the seminar. They answered on a 5 -point rating scale $(1=$ never again, $5=$ very often $)$. They were then asked whether the course had encouraged them to believe that the skills that are necessary for the teaching profession are learnable $(1=$ did not encourage me, 5 = encouraged me). The next question asked them to identify the three most important topics about CM that were still present in their memory. At this point, the respondents were given enough space to answer freely.

Finally, the teacher students were asked to freely explain which content from the seminar they expected to use in their professional lives. In the end, they gave their general evaluation of the seminar's usefulness $(1=$ did not learn anything useful, 5 = learned many relevant things).

\section{Results}

\subsection{Data Preparation}

All data were analyzed using standard statistical software (SPSS version 21). All scales were checked with respect to their reliability and showed values between $\alpha=.68$ and $\alpha=.85$ (for more detail see Table 2). All calculated scores were scaled in such a way that increasing values on the variables indicated the desired outcome.

The teacher educators did not exert a significant influence on the variables $(F=1.26)$; hence, this variable is not mentioned in the results.

\subsection{Statistical Analysis}

First, a repeated-measures analysis with the various subscales as dependent measures and the group (LGR, MGR, HGR, CG) as the factor was calculated. Then tests within subjects-contrasts were computed.

\subsection{Results of the Pre-Post Design at T1 and T2}

Quantitative data. For an overview of the statistical parameters, see Table 2. The results showed a significant change from T1 to T2, F $(9,100)=15.30, p<.001, \eta^{2}=.5$. On tests within-subjects contrasts, significant effect sizes were obtained from T1 to T2, except for the dimensions of cooperation and education readiness, though the self-reported perception of complexity increased from $\mathrm{T} 1$ to $\mathrm{T} 2, F=37.12, p<.001, \eta^{2}=.26$, pro-sociality increased, $F=3.93 p<.05, \eta^{2}=.04$, knowledge about CM increased, $F=16.33, p<.001, \eta^{2}=.13$, self-efficacy increased, $F=77.97, p<.001, \eta^{2}=.42$, attitudes toward the profession improved, $F=3.65, p<.06, \eta^{2}=.033$, and the training was rated more positively at T2 in comparison with the previous training, $F=38.74, p<.001$, $\eta^{2}=.26$. On the other hand, the results with respect to the dimension of self-efficacy, qualified by an interaction between time and group, showed only a trend, $F(27,306)=1.47, p<.07, \eta^{2}=.16$. By combining all the three 
Table 2. Self-reports at $\mathrm{T} 1$ and $\mathrm{T} 2(\mathrm{~N}=110)$.

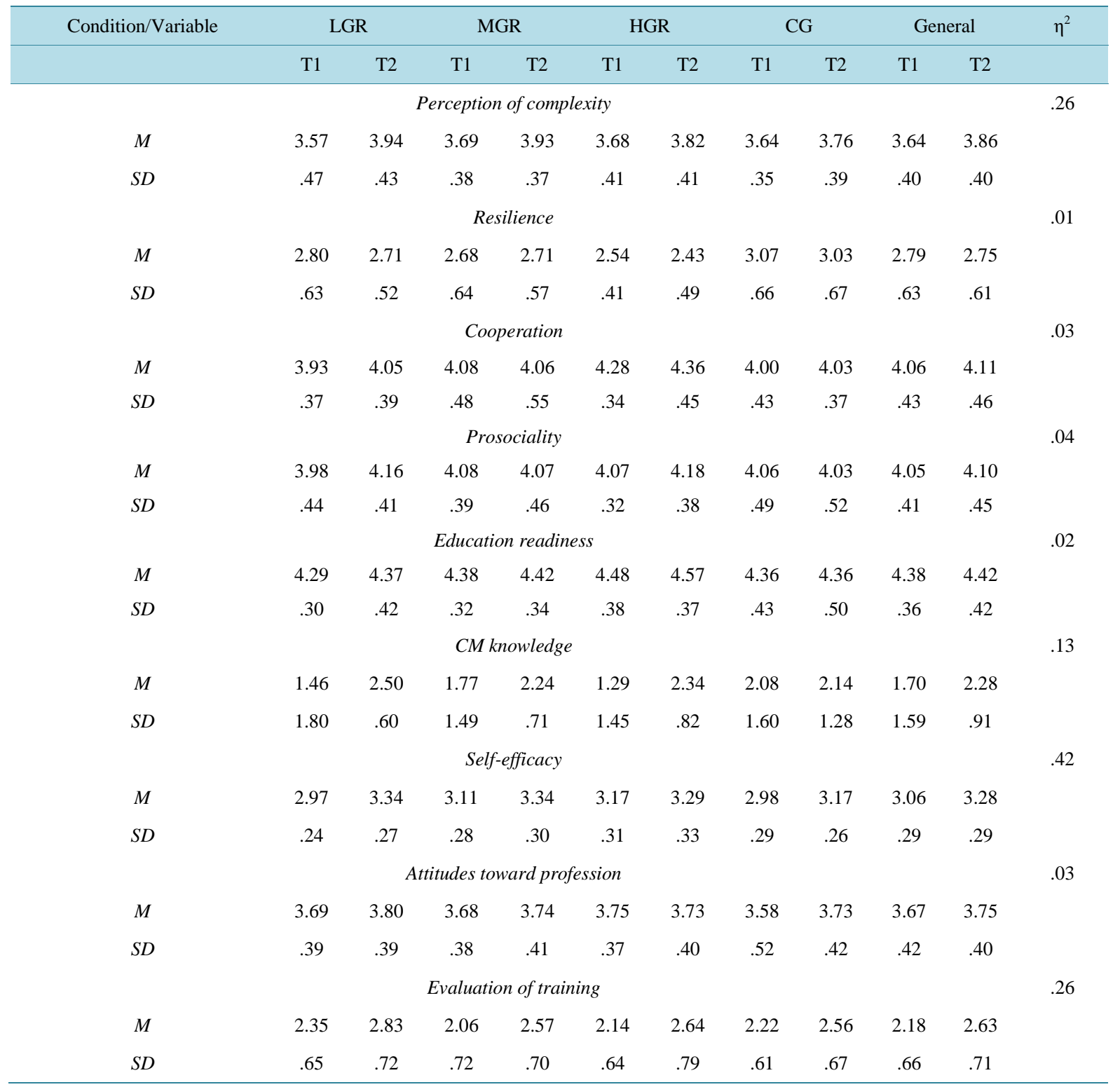

Note. LGR: Low Grade of Realism; MGR: Medium Grade of Realism; HGR: High Grade of Realism; CG: Control Group. Higher values indicate greater change on the variable according to the desired effects. Perception of complexity (T1: $\alpha=.68,9$ items, T2: $\alpha=.72$, 9 items); Resilience (T1: $\alpha=.68,8$ items, T2: $\alpha=.73,8$ items); Cooperation (T1: $\alpha=.78,12$ items, T2: $\alpha=.78,12$ items); Prosociality (T1: $\alpha=.76,10$ items, T2: $\alpha=.72$, 10 items); Education readiness (T1: $\alpha=.81,14$ items, T2: $\alpha=.85$, 14 items); CM knowledge (T1: $\alpha=.87,2$ items, T2: $\alpha=.81,2$ items); Self-efficacy (T1: $\alpha=.60,7$ items, T2: $\alpha=.87,7$ items); Attitudes toward profession (T1: $\alpha=.71,2$ items, T2: $\alpha=.84,2$ items).

realism groups into one treatment group called the CM group and comparing the changes in all items combined (T1: $\alpha=.77 ; \mathrm{T} 2: \alpha=.87)$, the general change in the self-reports became more pronounced, $F(1,108)=139.67$, $p<.001, \eta^{2}=.56$, and an interaction between the time and group could also be identified, $F(1,198)=4.90, p<.05$, $\eta^{2}=.04$, in such a way that the combination of all three treatment groups $(M T 1=3.55, S D=0.20 ; M T 2=3.83$, $S D=0.22 ; N=79$ ) reported a larger increase in their self-reports in the desired direction than the control group $(M T 1=3.59, S D=0.23 ; M T 2=3.77, S D=0.31 ; N=31)$.

\subsection{Reflection Reports of the Teacher Students in the HGR Group: Qualitative Data}

The reflection reports made by the teacher students in the HGR group were categorized according to the seminar 
content that they referred to as relevant. After categorizing the content, we collected data about the frequency of relevant seminar topics after they completed the theoretical phase and after they completed the practice phase. Two experts independently categorized the teacher students' statements according to these topics. With a few exceptions, all of their statements could be explicitly categorized.

An analysis of 25 reflection reports showed that 22 people (88\%) named REBT as relevant in the theory phase. Other issues were mentioned rarely (social perception: 13 people, 52\%; design of the learning environment: 11 people, 44\%; CM research: 8 people, 32\%; Positive Behavior Support Research: 4 people, 16\%; pupil-teacher interaction: 3 people, 12\%). The reasons for the relevance of REBT could be related to three themes. First, teacher students argued that with the knowledge of REBT principles, they learned to perceive other people in a more differentiated manner (e.g., "With the ABC model of Ellis, I've learned to evaluate the behavior of people differently and to better understand them"). Second, the teacher students saw REBT as a useful tool for guiding them to interact with students more effectively (e.g., "Especially since we have learned this behavior model, I can now imagine how to solve behavioral problems that may occur in my class. The theoretical basis of rational and irrational beliefs and the subsequent rational or irrational consequences have given me some insight into the mindset of my future students. I feel better prepared for my future job as a teacher to act competently or preventatively in any problematic situation”). Third, a large proportion of their statements were concerned with the application of REBT to the self, thus, as a Technology of the Self (e.g., "The model can be used to reflect on oneself, and I can see some situations from a different perspective"). It was also obvious that REBT was used by some of the teacher students in everyday situations as a Technology of the Self (e.g., "The ABC model is important not only for my later employment as a teacher, but even now, in everyday situations").

Only the reports of 14 people were available for the evaluation of the reflections after the practice phase. Here, the focus of important topics shifted clearly from scientific concepts to practical implications. The teacher students mostly mentioned situations in which they received feedback from their teacher educators (10 persons, 71.43\%); the lesson plan was also mentioned frequently (9 persons, 24.29\%). Students mostly identified a combination of theory and practice as successful (9 persons, 24.29\%). The only two theoretical references that were explicitly mentioned as useful in the practice phase were, on one hand, the theoretical concepts for the design of the learning environment from ecological psychology (8 persons, 57.14\%) and REBT. Six people (42.86\%) mentioned REBT as a major theory for them. The reasons already mentioned above appeared again. The following statements provide some examples of the reasons: "To me, the ABC model is a tool that I can use to reflect on my own behavior. This was especially useful if you were in a critical situation and acted incorrectly. One could reflect on one's own behavior constructively and actually learn from the mistakes"; "Emotional situations can be much better handled with REBT. I think it's important to face reality because only those who begin to face it can make a difference"; "The ABC model became a source for laying a good foundation. It helped me deal with the problems more specifically and look for alternatives.”

\subsection{Usefulness after 6 Months (T3)}

Quantitative data. All of the 29 students who sent back the electronically mailed questionnaire in 6 months, had dealt with $\mathrm{CM}$ after the seminar $(M=3.41$; $S D=0.91)$. About $50 \%$ reported values that were higher than the middle of the scale. When asked whether the competencies for the teaching profession were learnable, the mean was $M=4.14(S D=0.69)$. No teacher student indicated a value that was below the middle of the scale. Overall, $82 \%$ of the teacher students indicated values above the middle of the scale. They all gave high evaluations of the usefulness of the content $(M=4.10 ; S D=0.82)$. Approximately $93 \%$ of the students gave ratings that were above the middle of the scale.

Qualitative data. The answers about the three most relevant topics were categorized. The teacher students were able to identify three concepts. In the first topic, REBT and the REE were mentioned by $51.7 \%$ of all respondents, followed by the content of CM (17.2\%) and the content of environmental psychology (13.8\%). Other topics such as a Positive Behavior Support System and social psychological theories were named by 6.9\%, and didactic issues were mentioned by $3.4 \%$ of the respondents. In the second topic, again, REBT and REE were named by $44.8 \%$ of the respondents, followed by a Positive Behavior Support System (20.7\%) and topics of ecological psychology (13.8\%). Social psychological content, CM content, and didactic subjects were comparatively rarely mentioned (each 6.7\%). In third place, REBT and REE were mentioned by 34.15\% of the respondents, topics of CM by 27.6\%, followed by ecological psychology (13.8\%), a Positive Behavior Support System 
(10\%), and didactic subjects (3.4\%). A small proportion of these subjects (3.4\%) did not correspond with the course content.

When asked what the teacher students could imagine applying in their future professional lives, they often gave REBT and REE (37.9\%) as answers, but in many given answers, different combinations of the themes were mentioned (27.6\%). A Positive Behavior Support System (13.8\%), CM knowledge (10.3\%), social psychological subjects (3.4\%), and didactic subjects (3.4\%) were rarely mentioned.

\section{Discussion}

\subsection{Answers to the Research Questions}

The results suggest the following answers to our research questions: CM Contents were evaluated quite positively by the teacher students. This result is consistent with Cooper and Yan (2015) and O'Neill and Stephenson (2012) studies. After the completion of CM teacher students felt better prepared.

In addition, our results show that even in comparison with the content of CM, the teacher students considered the included Technology of the Self, REBT, to be particularly useful for various challenges at school. Not only was it named much more frequently when it came to identifying the relevant seminar content, but also the teacher students made various statements indicating that they saw a relevant theory-practice transfer.

The transfer of the seminar content seems to have succeeded. Here, however, the data showed that providing the students with a high degree of realism did not necessarily pay off. In all three CM groups, the subjective impression that the relevant skills were acquired was higher than in the control group. But also in the control group, the teacher students felt better prepared in general for professional life after the seminar than before the seminar. However, these patterns of results may have been influenced by changes in internal reference standards and might reflect a response shift (Grossman, 2008).

Additionally, we gain some knowledge about the teacher students transfer problems: The reflection reports of the students in the HGR group clearly showed that the theoretical knowledge was suppressed in the phase that the students were engaged in teaching. Nevertheless, it can also be concluded that REBT still had relevance for some students, although other more practical aspects were more prominently located in the foreground. But this remains a challenge in teacher education and still an open question, how to teach and train teacher students and novice teachers in the beginning of practicing. It seems to be a critical phase of using knowledge or only focusing on the practical challenges of teaching.

In summary, the results suggest that REBT as a Technology of the Self has a high subjective value for teacher students; the knowledge of the Technology of the Self seems to be even more important than the classical content of CM. Subjectively, it makes little difference whether this content is connected to a highly realistic setting or not.

Limitations of the interpretation of the results. We cannot conclude that a realistic approach did not offer a great value for the training of teacher students, as the sole collection of subjective self-reports made no statement about actual increases in competence and objectively verifiable knowledge. We can only conclude that REBT may be usefully included as a Technology of the Self in a CM seminar. The teacher students in the current study saw REBT as useful for relevant areas in the school context. Also due to the correlations outlined above between teachers' stress, self-reflection, and methods of interacting, REBT offers a validated and theoretically and empirically grounded instrument. Based on the fact that there is a fundamental disagreement on the question of how a teacher training should look and where it has to take place (Forzani, 2014; Wagner, 1991; Wiggins, 1996) we can formulate no reliable statement about the best way to transfer CM according to our investigation.

\subsection{Problems with New Content in Teacher Education}

It is difficult to integrate a new content into the teaching of CM, even if it is useful. As it was shown in the introductory part of the paper, a satisfactory way to integrate CM into the training of teacher students has not yet been identified, so teacher educators must constantly decide whether they should address the breadth or depth of knowledge (Jones, 2006). Introducing Technologies of the Self in general and introducing REBT in particular does not facilitate such a decision. However, showing how large the effective gaps in the training of basic skills are by uncovering and implementing the relevant content in Teacher Education magnifies the fact that a relevant 
problem exists.

\subsection{Resistance to Technologies of the Self in Teaching Profession}

We assume that resistance to the systematic teaching of Technologies of the Self, such as REBT in Teacher Education, has roots in issues other than just a resistance against a deeper and more comprehensive provision of CM skills in Teacher Education. At least four reasons for rejecting the teaching of Technologies of the Self in Teacher Education could be identified in discussions with the teacher students. These discussions en miniature certainly reflect more widespread societal beliefs. Technologies of the Self (i.e., individual competencies of self-reflection and self-regulation) often have the reputation of promoting adaptation to adverse conditions. At this point, it can be argued that many changes in school system are desirable; however, there is still the problem that teachers' unprofessional belief systems continue to interact negatively with students' adverse developmental trajectories. Also, working on external conditions (Activating events) is useful for improving the framework of central and important work and is important for a realistic assessment of this profession. The use of Technologies of the Self (beliefs and consequences) does not exclude closely working on external conditions, and working on the framework exclusively, provides no solution for those individuals who develop serious problems with their own dysfunctional beliefs. Finally, taking care of oneself in terms of applying Technologies of the Self is not an adaptation to poor conditions but an improvement of bad conditions. Teachers with poor skills are a significant part of such bad conditions. Finally, with the implementation of Technologies of the Self, we must still ask how people can take care of themselves in order to execute a satisfying (professional) life. This is often the initial requirement for making a change in order to improve poor conditions.

Another common belief, perhaps especially in Germany, concerns the question of authenticity. There is a common debate in seminars with teacher students that authenticity cannot be given if one's own true emotions are not expressed. It takes a lot of examples to convince teacher students that authenticity can also have other meanings than just to show "how it really is." With respect to key issues of REBT, a third debate is related to the fear of authority loss, such as regulating anger toward students. Teacher students are afraid that if they do not express serious negative emotions in conflict situations, they will get a reputation for being soft and be overly affected by the vagaries of the students. Finally, it should be noted that talking about emotions is an essential part of the psychology culture, but such expression has not yet been accentuated under all circumstances. Emotions and thoughts are still considered very private in large parts of the population. Many people perceive frank discussions about emotions in public situations as a form of danger. All these causes of resistance should be resolved in advance in the mediation of REBT in order to increase teacher students' cooperation and to facilitate the integration of REBT knowledge into their own self-concepts.

\section{Conclusion}

When considering the teacher students' perspectives and CM research, we conclude that CM is a necessary part of Teacher Education. CM Contents are broad and contain more than only facts. We assume that including a Technology of the Self makes CM Contents more complex, but more successful, especially when teacher students are accompanied for a longer time in the classroom as a part of their education.

\section{Outlook}

Although we and the teacher students found the integration of REBT as a Technology of the Self to be a part of their CM education, we do not know yet whether teacher students' subjective assessments would be supported by objective scrutiny or not. Are teachers who have a systematic Technology of the Self better teachers, and do they behave in a healthier manner in their professional lives? Is REBT superior to other methods? These issues require further exploration.

\section{Acknowledgements}

This research was a part of the Identity/Role-Orientation project in the "Bund-Länder-Program" and was supported by the German Bundesministery of Education and Research. We are most grateful to Andrea Schlicker und and Kristin Behnke, who assisted in collecting the data and coordinating the project. Many thanks to Bita 
Behravan for her valuable comments.

\section{Compliance with Ethical Standards}

The authors confirm that they complied with ethical guidelines.

\section{Conflict of Interest}

The authors have no conflict of interest.

\section{References}

Balli, S. J. (2011). Pre-Service Teachers’ Episodic Memories of Classroom Management. Teaching and Teacher Education, 27, 245-251. http://dx.doi.org/10.1016/j.tate.2010.08.004

Bauer, J., Unterbrink, T., Hack, A., Pfeifer, R., Buhl-Grießhaber, V., Müller, U., Wesche, H., Frommhold, M., Seibt, R., Scheuch, K., \& Wirsching, M. (2007). Working Conditions, Adverse Effects and Mental Health Problems in a Sample of 949 German Teachers. International Archives of Occupational and Environmental Health, 80, 442-449. http://dx.doi.org/10.1007/s00420-007-0170-7

Bitan, K., Haep, A., \& Steins, G. (2013). Psychology of Emotion and Its Application in Educational Settings. In C. Mohiyeddini, M. Eysenck, \& S. Bauer (Eds.), Handbook of Psychology of Emotions: Recent Theoretical Perspectives and Novel Empirical Findings (Vol. 1, pp. 101-114). New York: Nova Publisher.

Black, S. (2003). Stressed out in the Classroom. American School Board Journal, 190, 36-38.

Blömeke, S., Buchholtz, N., Suhl, U., \& Kaiser, G. (2014). Resolving the Chicken-Or-Egg Causality Dilemma: The Longitudinal Interplay of Teacher Knowledge and Teacher Beliefs. Teaching and Teacher Education, 37, 130-139.

http://dx.doi.org/10.1016/j.tate.2013.10.007

Cooper, P., \& Yan, Z. (2015). Some Possible Effects of Behaviour Management Training on Teacher Confidence and Competence: Evidence from a Study of Primary School Teachers in Hong Kong. Educational Studies, 41, 156-170. http://dx.doi.org/10.1080/03055698.2014.955739

David, D., Lynn, J., \& Ellis, A. (2010). Rational and Irrational Beliefs. New York: Oxford University Press.

Den Brok, P., \& Levy, J. (2005). Teacher-Student Relationships in Multicultural Classes: Reviewing the Past, Preparing the Future. International Journal of Educational Research, 43, 72-88. http://dx.doi.org/10.1016/j.ijer.2006.03.007

Doll, B. (2013). Enhancing Resilience in Classrooms. In S. Goldstein, \& R. B. Brooks (Eds.), Handbook of Resilience in Children (2nd ed., pp. 399-409). New York: Springer. http://dx.doi.org/10.1007/978-1-4614-3661-4_23

Dollase, R. (2012). Classroom Management: Theorie und Praxis des Umgangs mit Heterogenität (Classroom Management: Theory and Practice of Dealing with Heterogenity). Schulmanagement Handbuch, 142, München: Oldenbourg.

Ellis, A. (1994). Reason and Emotion in Psychotherapy. New York: Birch Lange Press.

Evertson, C. M., \& Weinstein, C. S. (2006). Classroom Management as a Field of Inquiry. In C. M. Evertson, \& C. S. Weinstein (Eds.), Handbook of Classroom Management: Research, Practice, and Contemporary Issues (pp. 3-16). Mahwah, NJ: Lawrence Erlbaum Associates.

Fleming, J. L., Mackrain, M., \& LeBuffe, P. A. (2013). Caring for the Caregiver: Promoting the Resilience of Teachers. In S. Goldstein, \& R. B. Brooks (Eds.), Handbook of Resilience in Children (2nd ed., pp. 349-370). New York: Springer. http://dx.doi.org/10.1007/978-1-4614-3661-4_22

Forzani, F. M. (2014). Understanding “Core Practices” and "Practice-Based” Teacher Education: Learning from the Past. Journal of Teacher Education, 65, 357-368. http://dx.doi.org/10.1177/0022487114533800

Foucault, M. (1984). Histoire de la sexualité: I La volonté de savoir. Paris: Gallimard.

Friedman, I. A. (1995). Student Behavior Patterns Contributing to Teacher Burnout. Journal of Educational Research, 88, 281-289. http://dx.doi.org/10.1080/00220671.1995.9941312

Friedman, I. A. (2006). Classroom Management and Teacher Stress and Burnout. In C. M. Evertson, \& C. S. Weinstein (Eds.), Handbook of Classroom Management: Research, Practice, and Contemporary Issues (pp. 925-944). Mahwah, NJ: Lawrence Erlbaum Associates.

Grossman, P. (2008). On Measuring Mindfulness in Psychosomatic and Psychological Research. Journal of Psychosomatic Research, 64, 405-408. http://dx.doi.org/10.1016/j.jpsychores.2008.02.001

Hamre, B. K., \& Pianta, R. C. (2001). Early Teacher-Child Relationships and the Trajectory of Children’s School Outcomes through Eighth Grade. Child Development, 72, 625-638. http://dx.doi.org/10.1111/1467-8624.00301 
Hamre, B. K., \& Pianta, R. C. (2005). Can Instructional and Emotional Support in the First-Grade Classroom Make a Difference for Children at Risk of School Failure? Child Development, 76, 949-967.

http://dx.doi.org/10.1111/j.1467-8624.2005.00889.x

Hastings, R. P., \& Bham, M. S. (2003). The Relationship between Student Behaviour Patterns and Teacher Burnout. School Psychology International, 24, 115-127. http://dx.doi.org/10.1177/0143034303024001905

Hattie, J. (2009). Visible Learning. London: Routledge.

Jones, V. (2006). How Do Teachers Learn to Be Effective Classroom Managers? In C. M. Evertson, \& C. S. Weinstein (Eds.), Handbook of Classroom Management: Research, Practice, and Contemporary Issues (pp. 887-908). Mahwah, NJ: Lawrence Erlbaum Associates.

Kanning, U. P., Herrmann, C., \& Böttcher, W. (2011). FIBEL. Feedback-Inventar zur berufsbezogenen Erstorientierung für Lehramtsstudierende. Göttingen: Hogrefe.

Knaus, W. (1974). Rational-Emotive Education: A Manual for Elementary School Teachers. New York: Institute for Rational Living.

Kokkinos, C. M., Panayiotou, G., \& Davazoglou, A. M. (2005). Correlates of Teacher Appraisals of Student Behaviors. Psychology in the Schools, 42, 79-89. http://dx.doi.org/10.1002/pits.20031

Kounin, J. S. (1970). Discipline and Group Management in Classrooms. New York: Holt, Rinehart and Winston.

Leavy, A. M., McSorley, F. A., \& Bote, L. A. (2007). An Examination of What Metaphor Construction Reveals about the Evolution of Preservice Teachers' Beliefs about Teaching and Learning. Teaching and Teacher Education, 23, $1217-1233$. http://dx.doi.org/10.1016/j.tate.2006.07.016

Liew, J., Chen, Q., \& Hughes, J. N. (2010). Child Effortful Control, Teacher-Student-Relationships, and Achievement in Academically At-Risk Children: Additive and Interactive Effects. Early Childhood Research Quarterly, 25, 51-64. http://dx.doi.org/10.1016/j.ecresq.2009.07.005

Loewenberg Ball, D., \& Forzani, F. M. (2009). The Work of Teaching and the Challenge for Teacher Education. Journal of Teacher Education, 60, 497-511. http://dx.doi.org/10.1177/0022487109348479

Loewenberg Ball, D., \& Forzani, F. M. (2010). Teaching Skillful Teaching. Educational Leadership, 68, 40-45.

Löfström, E., \& Poom-Valickis, K. (2013). Beliefs about Teaching: Persistent or Malleable? A Longitudinal Study of Prospective Student Teachers' Beliefs. Teaching and Teacher Education, 35, 104-113. http://dx.doi.org/10.1016/j.tate.2013.06.004

Maag, J. W. (2001). Powerful Struggles: Managing Resistance, Building Rapport. Longmont, CO: Sopris Press.

Maag, J. W. (2008). Rational-Emotive Therapy to Help Teachers Control Their Emotions and Behavior When Dealing with Disagreeable Students. Intervention in School and Clinic, 44, 52-57. http://dx.doi.org/10.1177/1053451208318680

Maslach, C., \& Leiter, M. P. (1997). The Truth about Burnout. San Francisco, CA: Jossey-Bass.

Nucci, C. (2002). The Rational Teacher: Rational Emotive Behavior Therapy in Teacher Education. Journal of RationalEmotive \& Cognitive-Behavior Therapy, 20, 15-32. http://dx.doi.org/10.1023/A:1015176819937

O’Neill, S., \& Stephenson, J. (2012). Does Classroom Management Coursework Influence Pre-Service Teachers’ Perceived Preparedness or Confidence? Teaching and Teacher Education, 28, 1131-1143.

http://dx.doi.org/10.1016/j.tate.2012.06.008

Piwowar, V., Thiel, F., \& Ophardt, D. (2013). Training in Service Teachers' Competencies in Classroom Management. A Quasi-Experimental Study with Teachers of Secondary Schools. Teaching and Teacher Education, 30, 1-12. http://dx.doi.org/10.1016/j.tate.2012.09.007

Rauin, Z., \& Meier, U. (2007). Subjektive Einschätzungen des Kompetenzerwerbs in der Lehramtsausbildung (Subjective Estimations of Competence Acquisition in Teacher Education). In M. Lüders, \& J. Wissinger (Eds.), Forschung zur Lehrerbildung (pp. 103-133). Münster: Waxmann.

Reyes, J. A., Elias, M. J., Parker, S. I., \& Rosenblatt, J. L. (2013). Promoting Educational Equity in Disadvantaged Youth: The Role of Resilience and Social-Emotional Learning. In S. Goldstein, \& R. B. Brooks (Eds.), Handbook of Resilience in Children (2nd ed., pp. 349-370). New York: Springer. http://dx.doi.org/10.1007/978-1-4614-3661-4_20

Rushton, S. P. (2000). Student Teacher Efficacy in Inner-City Schools. The Urban Review, 32, 365-383. http://dx.doi.org/10.1023/A:1026459809392

Schaarschmidt, U. (2009). Beanspruchung und Gesundheit im Lehrberuf. In K. Beck, \& D. Sembill (Eds.), Lehrerprofessionalität, Bedingungen, Genese, Wirkungen und ihre Messung (Professionalism of Teachers, Conditions, Genesis and Effects and Its Measurement) (pp. 604-616). Basel: Beltz.

Schmitz, G. S., \& Schwarzer, R. (2000). Selbstwirksamkeitsorientierung von Lehrern: Längsschnittstudie mit einem neuen Instrument (Self-Efficacy of Teachers: A Longitudinal Study with a New Measurement). Pädagogische Psychologie, 14, 12-25. http://dx.doi.org/10.1024//1010-0652.14.1.12 
Schwarzer, R., Schmitz, G. S., \& Tang, C. (2000). Teacher Burnout in Hong Kong and Germany-A cross-Cultural Validation of the Maslach Burnout Inventory. Anxiety, Stress, and Coping, 13, 309-326.

Shechtman, Z., \& Leichtentritt, J. (2004). Affective Teaching: A Method to Enhance Classroom Management. European Journal of Teacher Education, 27, 323-333. http://dx.doi.org/10.1080/0261976042000290822

Sleeter, C. (2008). Equity, Democracy, and Neoliberal Assaults on Teacher Education. Teaching and Teacher Education, 24, 1947-1957. http://dx.doi.org/10.1016/j.tate.2008.04.003

Steins, G. (2014). Sozialpsychologie des Schulalltags. Band 1: Grundlagen und Anwendungen (Social Psychology of the School, Volume 1: Basics and Applications). Lengerich: Pabst Science Publishers.

Steins, G., \& Haep, A. (2014). Soziales Lernen in der Schule. Angewandte Sozialpsychologie für Lehrende und Lernende in Schule und Universität (Social Learning in School. Applied Social Psychology for Teachers in School and University). Zeitschrift für Gruppendynamik und Organisationsberatung, 45, 5-23. http://dx.doi.org/10.1007/s11612-014-0234-6

Steins, G., \& Haep, A. (2015). Social Learning and Rational-Emotive Education: An Exploratory Investigation of Students' Perceptions. Psychology, 6, 1096-1107. http://dx.doi.org/10.4236/psych.2015.69107

Steins, G., Bitan, K., \& Haep, A. (2014). Sozialpsychologie des Schulalltags. Band 2: Im Klassenzimmer (Social Psychology of the School. Volume 2: In the Classroom). Lengerich: Pabst Science Publishers.

Steins, G., Wittrock, K., \& Haep, A. (2015). Contents of Classroom Management: What Is Necessary, What Is Possible, How Is It in School? Manuscript in Review.

Stough, L. M. (2006). The Place of Classroom Management and Standards in Teacher Education. In C. M. Evertson, \& C. S. Weinstein (Eds.), Handbook of Classroom Management: Research, Practice, and Contemporary Issues (pp. 909-924). Mahwah, NJ: Lawrence Erlbaum Associates.

Stoughton, E. H. (2007). “How Will I Get Them to Behave?”: Pre-Service Teachers Reflect on Classroom Management. Teaching and Teacher Education, 23, 1024-1037. http://dx.doi.org/10.1016/j.tate.2006.05.001

Trent, J. (2013). From Campus to Classroom: A Critical Perspective on Approximations of Practice in Teacher Education. Research Papers in Education, 28, 571-594. http://dx.doi.org/10.1080/02671522.2012.710246

Ullrich, A., Lambert, R. G., \& McCarthy, C. J. (2012). Relationship of German Elementary Teachers' Occupational Experience, Stress, and Coping Resources to Burnout Symptoms. International Journal of Stress Management, 19, 333-342. http://dx.doi.org/10.1037/a0030121

Unterbrink, T., Pfeifer, R., Krippeit, L., Zimmermann, L., Rose, U., Joos, A., Hartmann, A., Wirsching, M., \& Bauer, J. (2012). Burnout and Effort-Reward Imbalance Improvement for Teachers by a Manual-Based Group Program. International Archives of Occupational and Environmental Health, 85, 667-674. http://dx.doi.org/10.1007/s00420-011-0712-x

van Tartwijk, J., den Brok, P., Veldman, I., \& Wubbels, T. (2009). Teacher’s Practical Knowledge about Classroom Management in Multicultural Classrooms. Teaching and Teacher Education, 25, 453-460. http://dx.doi.org/10.1016/j.tate.2008.09.005

Wagner, A. (1991). Educating Teachers. The OECD Observer, 169, 17-19.

Walkington, J. (2005). Becoming a Teacher: Encouraging Development of Teacher Identity through Reflective Practice. Asia-Pacific Journal of Teacher Education, 33, 53-64. http://dx.doi.org/10.1080/1359866052000341124

Warren, J. M. (2013). School Counselor Consultation: Teachers’ Experiences with Rational Emotive Behavior Therapy. Journal of Rational-Emotive \& Cognitive Behaviour Therapy, 31, 1-15. http://dx.doi.org/10.1007/s10942-011-0139-z

Weber, A., Weltle, D., \& Lederer, P. (2004). Frühinvalidität im Lehrerberuf: Sozial-und arbeitsmedizinische Aspekte (Early Job Leaving: Perspectives of Medicine). Deutsches Ärzteblatt, 101, 850-859.

Weinstein, C. S., Tomlinson-Clarke, S., \& Curran, M. (2004). Toward a Conception of Culturally Responsive Classroom Management. Journal of Teacher Education, 55, 25-38. http://dx.doi.org/10.1177/0022487103259812

Wiggins, G. (1996). Anchoring Assessment with Exemplars: Why Students and Teachers Need Models. Gifted Child Quarterly, 40, 66-69. http://dx.doi.org/10.1177/001698629604000203

Wilton, T., \& Steins, G. (2012). Umgang von Lehrenden mit Stress: Zur Bedeutung des Konzeptes rationaler Gedanken in der Lehrerausbildung (Dealing with Stress: Rational Thinking in Teacher Education). Zeitschrift für Rational-Emotive \& Kognitive Verhaltenstherapie, 23, 7-32.

Zeichner, K. (2003). The Adequacies and Inadequacies of Three Current Strategies to Recruit, Prepare, and Retain the Best Teachers for All Students. Teachers College Record, 105, 490-519. http://dx.doi.org/10.1111/1467-9620.00248

Zeichner, K. (2005). Becoming a Teacher Educator: A Personal Perspective. Teaching and Teacher Education, 21, 117-124. http://dx.doi.org/10.1016/j.tate.2004.12.001 